\title{
Removal of cadmium (II) from aqueous solutions by two kinds of manganese coagulants
}

\author{
Yongpeng Xu ${ }^{1,2, *}$, Leisan Yang ${ }^{2}$, Jingkun Yang ${ }^{2}$ \\ ${ }^{1 *}$ State Key Laboratory of Urban Water Resource and Environment, Harbin Institute of Technology, Harbin 150090, CHINA \\ ${ }^{2}$ School of Municipal and Environmental Engineering, Harbin Institute of Technology, Harbin 150090, CHINA \\ *Corresponding author: e-mail: xuyongpeng123@163.com, Tel 13946110707
}

\begin{abstract}
The study presents the removal of trace cadmium (II) in water with batch experiments by two kinds of manganese coagulants, $\mathrm{HMO}$ prepared from $\mathrm{KMnO}_{4}$ and $\mathrm{Na}_{2} \mathrm{~S}_{2} \mathrm{O}_{3}$, and $\mathrm{HFMO}$ prepared from $\mathrm{KMnO}_{4}$ and $\mathrm{FeSO}_{4}$. Various parameters such as turbidity, $\mathrm{pH}$, initial concentration of $\mathrm{Cd}(\mathrm{II})$ and coagulation time were investigated. The results showed that the cadmium can be better removed using $\mathrm{HMO}$ than by HFMO. With $\mathrm{pH}=6.72$ and the $\mathrm{Cd}(\mathrm{II})$ initial concentration, $1 \mathrm{mg} / \mathrm{L}$, the dosage of $\mathrm{HMO}$ is $20 \mathrm{mg} / \mathrm{L}$, as the removal rate of cadmium is $85.04 \%$. However, with $\mathrm{pH}=8.03$ and the $\mathrm{Cd}(\mathrm{II})$ initial concentration, $1 \mathrm{mg} / \mathrm{L}$, the dosage of HFMO is $20 \mathrm{mg} / \mathrm{L}$, as the removal rate of cadmium is $53.23 \%$. The effectiveness of these two kinds of manganese coagulants for removal of cadmium and turbidity in natural water from Canal Jingmi in Beijing performed better when HMO is used than HFMO used. The paper indicated that HMO was an easily available and effective coagulant for the disposal of trace cadmium in water.
\end{abstract}

Keywords: Cadmium (II), HMO, HFMO, coagulation, binding site

\section{Introduction}

Contamination of the aqueous environments by heavy metals is a worldwide environmental problem due to their toxic effects and accumulation through the food chain. Cadmium is a heavy metal with the greatest potential hazard to humans and the environment due to its acute toxicity (Ozturk et al., 2009). The health effects of Cd (II) on human include nausea, vomiting, diarrhea, muscle cramp, salivation, loss of calcium from bones, yellow coloration of teeth (cadmium ring formation),reduction of red blood cells, damage of bone marrow, hypertension, kidney failure following oral ingestion, lung irritation, chest pain, and loss of sense of smell after inhalation. Chronic cadmium poisoning produces proteinuria and affects the proximal tubules of kidney, causing formation of kidney stones (Naiya et al., 2009). Drinking water regulations have continued to lower the maximum contaminant level (MCL) for cadmium based on more information about health effects. United States Environmental Protection Agency (USEPA) and the Ministry of Health of PR China have revised the (MCL) for Cd in drinking water from $10 \mu \mathrm{g} / \mathrm{L}$ to $5 \mu \mathrm{g} / \mathrm{L}$. The World Health Organization set the tolerance limits for cadmium concentration in drinking water as $3 \mu \mathrm{g} / \mathrm{L}$.

The most commonly used methods for the removal of cadmium ions from aqueous solution include, chemical precipitation (Christensen et al., 1982; Brantner et al., 1984; Wu et al., 2010), ion exchange (Bhattacharya et al., 1984; Hrudey, 1984), solvent extraction (Stenstrom, 1987; Casas et al., 1986), dialysis/electro-dialysis (Marder et al., 2003), reverse osmosis (Mazid et al., 1984), supported liquid membrane (Tripathy et al., 2002), and adsorption (Sharma et al., 1998; Singh et al., 1998). Among them, chemical precipitation, ion exchange and solvent extraction are not economically viable to remove cadmium to low concentrations from aqueous solutions. Adsorption is one of the most effective approaches to cadmium removal over a wider range of $\mathrm{pH}$ values and at lower concentrations. However, adsorption needs long contact time to achieve equilibrium between adsorbate and adsorbent, which restrains its practical application in water treatment (Gupta et al., 2002; Mohapatra et al., 2009; Das et al., 2006). Therefore, the stiffening of regulations generates strong demands to improve methods for removing cadmium from the water and controlling water treatment residuals. Coagulation is one of the most important processes in water treatment plant; as well it is one of the most effective methods of the removal of cadmium (Ayoub et al., 2001). Hydrous Manganese Dioxides (HMO) can exhibit 
a low $\mathrm{pH}$ point of zero charge $\left(\mathrm{pH}_{\mathrm{PZC}}\right)$ and can develop a large negative surface charge over the $\mathrm{pH}$ range of interest in most natural water (Tonkin et al., 2004). Many researchers have studied the adsorption characteristics of cadmium by HMO. However, little attention was paid to the usage of hydrous manganese as a coagulant.

The present study deals with a series of batch coagulation experiments to investigate and explore the feasibility of hydrous manganese dioxide as a coagulant for removal of cadmium. The effect of turbidity, $\mathrm{pH}$, and initial concentration of cadmium and coagulation time has been evaluated. Finally, the effectiveness of these two kinds of manganese coagulants was studied for removal of cadmium and turbidity in natural water from Canal Jingmi in Beijing.

\section{Materials and methods}

\subsection{Raw water}

All chemicals used in the experiment were of analytical grade. All solutions were prepared with deionized water. $\mathrm{CdCl}_{2} \cdot 5 / 2 \mathrm{H}_{2} \mathrm{O}$ was dissolved in DI water to prepare primary stock solution with $\mathrm{Cd}(\mathrm{II})$ concentration of $1000 \mathrm{mg} / \mathrm{L}$ every week. Hydrous manganese dioxide was employed as the coagulant in this study and was freshly prepared for each set of experiments. Background electrolyte solutions were prepared from the reagent-grade salts, $\mathrm{NaCl}$ and $\mathrm{NaHCO}_{3}$ (Guan et al., 2007). Turbidity of raw water was prepared by diatomaceous earth. Because the removal efficiency of cadmium by the manganese coagulant synthesized by potassium permanganate and ferrous sulfate was too low as the hydrogen ion generated, the raw water(2) spiked with $5 \mathrm{~mL}$, $0.1 \mathrm{~mol} / \mathrm{L} \mathrm{NaOH}$ in the coagulation stage. The quality of raw water is listed in Table 1.

Table 1. The quality of raw water

\begin{tabular}{|c|c|c|c|c|c|}
\hline NO. & $\mathrm{pH}$ & $\mathrm{Cd}^{2+} /(\mathrm{mg} / \mathrm{L})$ & $\mathrm{NaCl} /(\mathrm{mol} / \mathrm{L})$ & $\mathrm{NaHCO} /(\mathrm{mol} / \mathrm{L})$ & $\begin{array}{c}\text { Manganese } \\
\text { coagulant }\end{array}$ \\
\hline Raw water(1) & 6.72 & 1 & 0.05 & 0.0005 & $\begin{array}{c}\mathrm{KMnO}_{4^{-}} \\
\mathrm{Na}_{2} \mathrm{~S}_{2} O_{3}\end{array}$ \\
\hline Raw water(2) & 8.04 & 1 & 0.05 & 0.0005 & $\begin{array}{c}\mathrm{KMnO}_{4^{-}} \\
\mathrm{FeSO}_{4}\end{array}$ \\
\hline
\end{tabular}

The natural raw water was collected from Canal Jingmi in summer, with turbidity of $0.6 \mathrm{NTU}$, colority ranging from 1 to 2 , $\mathrm{COD}_{\mathrm{Mn}}$ of $1.85 \mathrm{mg} / \mathrm{L}$, and $\mathrm{pH}$ of 7.38 . Because the concentration of cadmium in Canal Jingmi is low, the natural raw water is spiked with $1 \mathrm{~mL} \mathrm{Cd}^{2+}$ stock solution.

\subsection{Materials}

The manganese coagulants were prepared by the process $\mathrm{KMnO}_{4}-\mathrm{Fe}\left(\quad\right.$ ) and $\mathrm{KMnO}_{4}-\mathrm{Na}_{2} \mathrm{~S}_{2} \mathrm{O}_{3}$, respectively.

$$
\begin{aligned}
& \mathrm{Na}_{2} \mathrm{~S}_{2} \mathrm{O}_{3}+2 \mathrm{KMnO}_{4}=2 \mathrm{MnO}_{2} \downarrow+\mathrm{Na}_{2} \mathrm{SO}_{4}+\mathrm{K}_{2} \mathrm{SO}_{3} \\
& 2 \mathrm{KMnO}_{4}+6 \mathrm{FeSO}_{4} \cdot 7 \mathrm{H}_{2} \mathrm{O}=2 \mathrm{MnO}_{2} \downarrow+6 \mathrm{Fe}(\mathrm{OH})_{3} \downarrow+5 \mathrm{H}_{2} \mathrm{SO}_{4}+\mathrm{K}_{2} \mathrm{SO}_{4}+28 \mathrm{H}_{2} \mathrm{O}
\end{aligned}
$$

HMO stands for the coagulant prepared by method (1). The primary ingredient of HMO is hydrous manganese dioxide, which accounts for $61.3 \%$ of the total amount of the precipitation (Yang et al., 2008). HFMO stands for the coagulant prepared by method (2), which consists of hydrous manganese dioxide and ferric hydroxide. From the equation (2), the mass ratio of $\mathrm{MnO}_{2} / \mathrm{Fe}(\mathrm{OH})_{3}$ is $1 / 3.69$. The dosage of $\mathrm{HMO}$ and HFMO is measured by the total amount of precipitation.

\subsection{Methods}

Jar tests were performed with a standard $1 \mathrm{~L}$ jar testing device to simulate a conventional coagulation/flocculation process. All glassware was cleaned by soaking in $10 \% \mathrm{HNO}_{3}$ and rinsed three times with distilled water.

If not otherwise specified, the jar testing procedure was initiated with rapid mixing at 300rpm for $2 \mathrm{~min}$ followed by $60 \mathrm{rpm}$ for $15 \mathrm{~min}$, consecutively. And then the samples were taken after $20 \mathrm{~min}$ sedimentation. Rapid mixing was started as soon as the prepared manganese coagulants were added into synthetic water containing $\mathrm{Cd}($ ). The initial $\mathrm{Cd}(\mathrm{)}$ concentration was $1 \mathrm{mg} / \mathrm{L}$ and the coagulant was applied at $20 \mathrm{mg} / \mathrm{L}$. Each experiment was carried out open to the atmosphere in (at least) duplicate. All experiments were performed with a constant ionic strength of $0.05 \mathrm{M} \mathrm{NaCl} .0 .0005 \mathrm{M} \mathrm{NaHCO}_{3}$ was added to provide the alkalinity. The $\mathrm{pH}$ values of the solutions were adjusted by adding $0.1 \mathrm{M}$ sodium hydroxide and $0.1 \mathrm{M}$ hydrochloric acid solutions. A high performance $\mathrm{pH}$ meter with a saturated $\mathrm{KCl}$ solution as electrolyte (Corning 350) was used to measure solution $\mathrm{pH}$ Daily

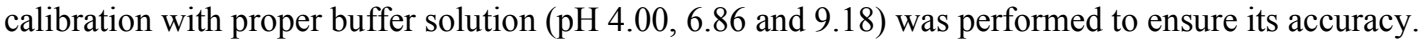

After reaction, the water was filtered immediately through $0.45 \mu \mathrm{m}$ pore size cellulose acetate membrane (MFS) and the filtrate was analyzed for remaining $\mathrm{Cd}$ concentration in the sample using atomic absorption spectrophotometry (AAS). 


\section{Result and Discussion}

\subsection{Removal efficiency by two manganese salts in synthetic water}

The removal of $\mathrm{Cd}$ by two manganese coagulants over the dosage range of $2-50 \mathrm{mg} / \mathrm{L}$, was demonstrated in Figure 1 . It was observed that the removal efficiency increased quickly as the increase of coagulant dose.

Adsorption is the main mechanism for the $\mathrm{Cd}(\mathrm{II})$ removal by manganese salts during coagulation. The $\mathrm{pH}_{\mathrm{pzc}}$ of the $\mathrm{HMO}$ is found to be 1.8 (Tripathy et al., 2006). So the HMO develops a large negative surface charge at pH 6.72. The Cd (II) was adsorbed onto the surface of HMO probably through electrostatic strength. The amount of the binding sites on the HMO surface increased with its dosage, consequently the removal efficiency increased quickly with the dosage of the HMO increasing. When the dosage of the $\mathrm{HMO}$ was more than $20 \mathrm{mg} / \mathrm{L}$, the remaining concentration of the residual cadmium ion was very low. And this restrained the adsorption of the cadmium. So the increase extent of the removal efficiency is small.

HFMO is constituted of ferric hydroxide and hydrous manganese dioxide. $\mathrm{The}_{\mathrm{pHzc}}$ of the HFMO is 4 (Guan et al., 2009). It can be speculated that hydrous manganese dioxide plays a major role in the removal of cadmium. There are two aspects impact on the removal of cadmium by HFMO. On the one hand, removal efficiency increases with the HFMO dosage increasing, On the other hand, the removal of cadmium is highly $\mathrm{pH}$-dependent.

The amount of hydrogen ions generated during the synthesis of HFMO increased with the HFMO dosage increasing. The removal efficiency of the cadmium declined with the decrease of the solution $\mathrm{pH}$ values. When the dosage of the HFMO was less than $28.14 \mathrm{mg} / \mathrm{L}$, the removal efficiency of the cadmium increased with the HFMO amount increasing. After the removal efficiency of the cadmium reached the plateau, it was mainly affected by the $\mathrm{pH}$ values of the solution and decreased with the decline of the $\mathrm{pH}$ values.

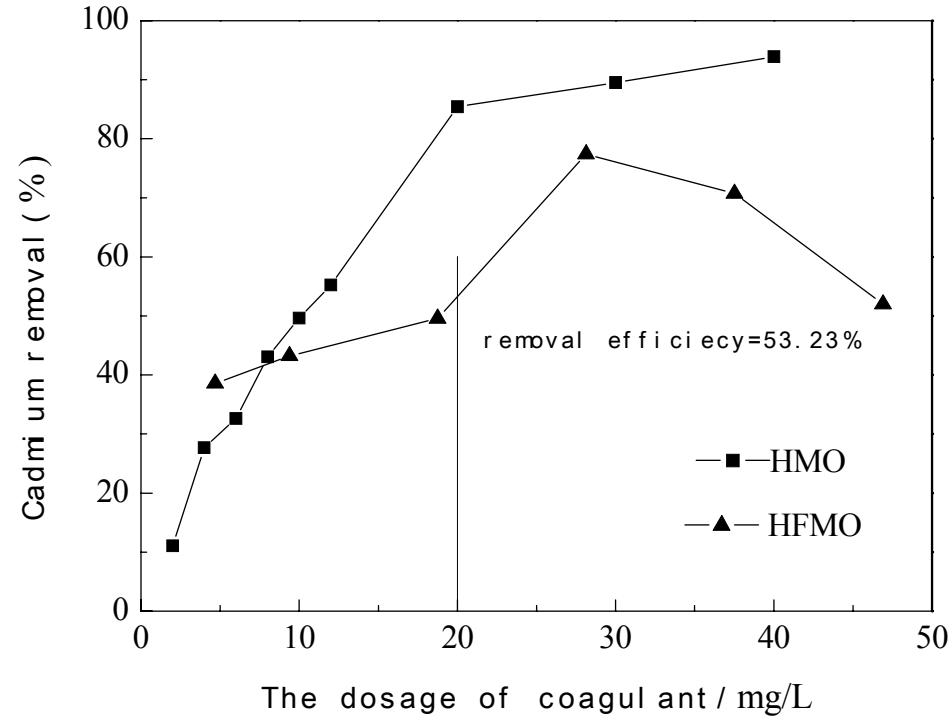

Figure 1. The removal efficiency of $\mathrm{Cd}(\quad)$ in synthetic water by HMO and HFMO

\subsection{Effect of turbidity}

Figure 2 shows the effect of the turbidity on removal efficiency of the Cd(II). It was observed that turbidity had little effect on the cadmium removal by HMO, Chen (2008) also reported that turbidity had no effect on the removal of cadmium by poly ferric sulfate. However, turbidity significantly promoted the cadmium removal by HFMO. When the turbidity was 3 NTU, the removal efficiency of cadmium is $97.57 \%$ increased by $20.16 \%$. Over the turbidity range from 3NTU to $90 \mathrm{NTU}$, the removal efficiency of the cadmium did not change greatly.

It is assumed that diatomaceous earth can absorb a certain amount of cadmium ions. But it takes up the same amount of binding sites. The adsorption capacity did not increase in the presence of the diatomaceous earth. As for HFMO, firstly the ferric hydroxide can absorb the diatomaceous earth; this led to the increase of the adsorption capacity of the HFMO. Secondly, diatomaceous earth adsorbed some hydrogen ions, which can be proved by the decrease of the $\mathrm{pH}$ value. This also increases the adsorption capacity of the HFMO. The increase of the turbidity did not increase the removal efficiency of the cadmium for the both manganese coagulants because the adsorption capacity for diatomaceous earth is also finite and the low concentration of residual cadmium restrains the adsorption of the cadmium. 


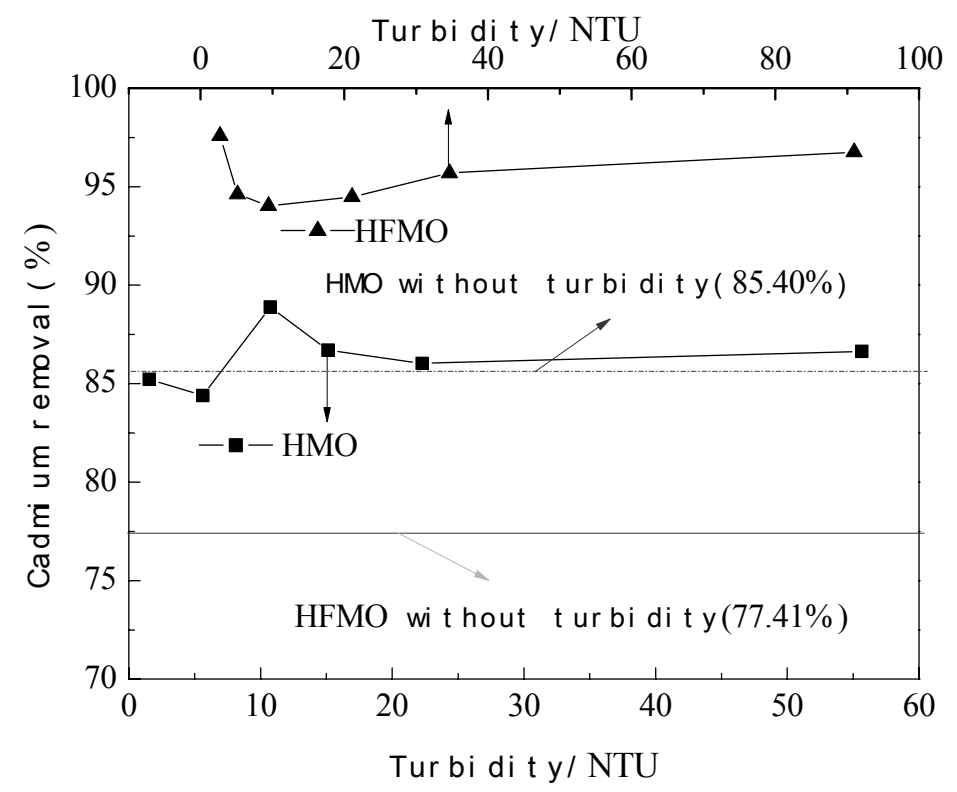

Figure 2. The effects of turbidity on the removal efficiency of $\mathrm{Cd}(\mathrm{II})$ in synthetic water by HMO and HFMO(The dosage of HMO and HFMO is $20 \mathrm{mg} / \mathrm{L}, 28.14 \mathrm{mg} / \mathrm{L}$, separately)

\subsection{Effect of $p H$}

The $\mathrm{pH}$ of the solutions has an important variable governing metal removal. In general, removal of cations is favored at $\mathrm{pH}>$ $\mathrm{pH}_{\mathrm{pzc}}$. The effect of $\mathrm{pH}$ on the removal of $\mathrm{Cd}^{2+}$ by the two manganese coagulants was studied by varying $\mathrm{pH}$ of the solution over the range of 2 11 using different concentration. As demonstrated in Figure 3, the removals of cadmium by two manganese coagulants were highly $\mathrm{pH}$-dependent. Cadmium removal at $\mathrm{pH} 2 \sim 4$ could be negligible. Removal efficiency of the cadmium dramatically increased as the $\mathrm{pH}$ increased from 4 to 9 . However, as the $\mathrm{pH}$ increased continuously the removal efficiency did not increase any more.

It is considered that alkalinity is beneficial to eliminate $\mathrm{Cd}^{2+}$. When the $\mathrm{pH}<8$, cadmium mainly exists as $\mathrm{Cd}^{2+}$ in solution, the adsorption led to the increase of cadmium removal. The increased removal efficiency at $\mathrm{pH}>8$ may be a combination of both adsorption and precipitation on the surface of the coagulants. Firstly, the adsorption capacity increases with increase of the amount of surface charge. Secondly, at $\mathrm{pH}>8$, the fraction of $\mathrm{Cd}(\mathrm{OH})^{+}, \mathrm{Cd}(\mathrm{OH})_{2}$ in the solution increase with increase of $\mathrm{pH}$. This also enhanced the cadmium removal.

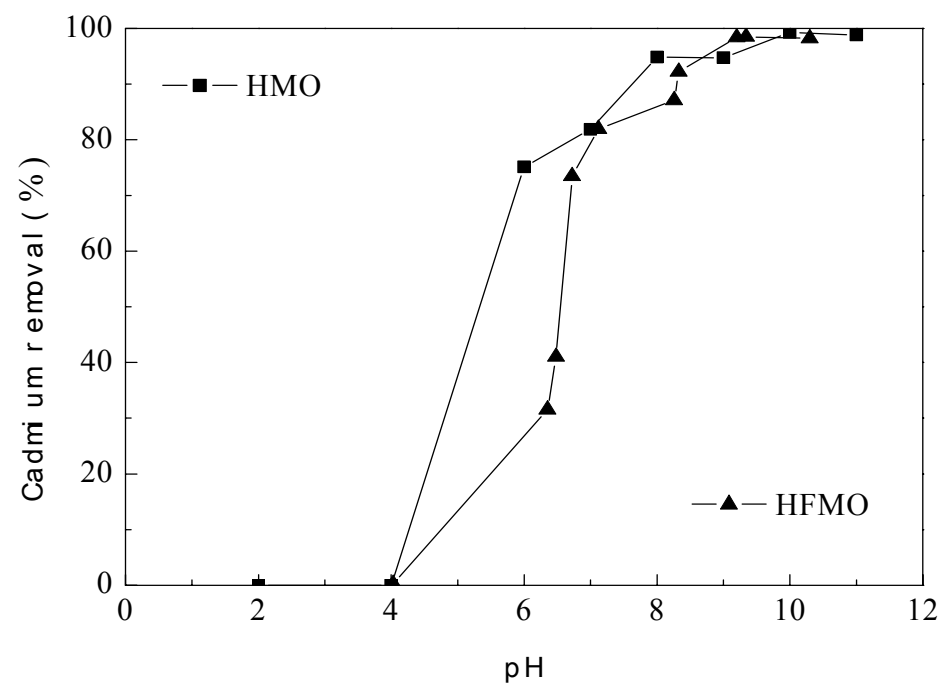

Figure 3. The effects of $\mathrm{pH}$ on the removal efficiency of $\mathrm{Cd}$ (II) in synthetic water by HMO and HFMO (The dosage of HMO and $\mathrm{HFMO}$ is $20 \mathrm{mg} / \mathrm{L}, 28.14 \mathrm{mg} / \mathrm{L}$, separately) 


\subsection{Effect of initial Cd(II)concentration}

Effect of initial Cd(II) concentration are shown in Figure 4. The cadmium removal increases with the increasing of the initial concentration, at the initial Cd(II) concentration less than $0.8 \mathrm{mg} / \mathrm{L}$. With increase in initial Cd(II) concentrations, more Cd(II) ions are left in the solution due to the saturation of the binding sites. A maximum removal efficiency of cadmium is $94.08 \%$, which was noted in Figure 4. As for HFMO, the removal of cadmium increased quickly over cadmium initial concentration $0.2-0.5 \mathrm{mg} / \mathrm{L}$. However, as the initial Cd(II) concentration increased continuously the removal efficiency did not increase any more. At the initial $\mathrm{Cd}(\mathrm{II})$ concentration over $1.13 \mathrm{mg} / \mathrm{L}$, the removal efficiency by HMO is larger than HFMO. Afterwards, the removal effect of cadmium by HFMO is better than HMO. This indicates that energetically less favorable sites become involved with increasing $\mathrm{Cd}(\mathrm{II})$ ion concentration in aqueous solution.

There are two kinds of binding sites, the lower and higher energy binding sites, on the surface of the coagulants. The binding sites with lower energy binding sites are available for $\mathrm{Cd}^{2+}$ when the initial $\mathrm{Cd}(\mathrm{II})$ concentration is high. The amount of highly energy binding sites of HMO is more than of HFMO. But the number of total binding sites of HMO is less than HFM (Tripathy et al., 2006).

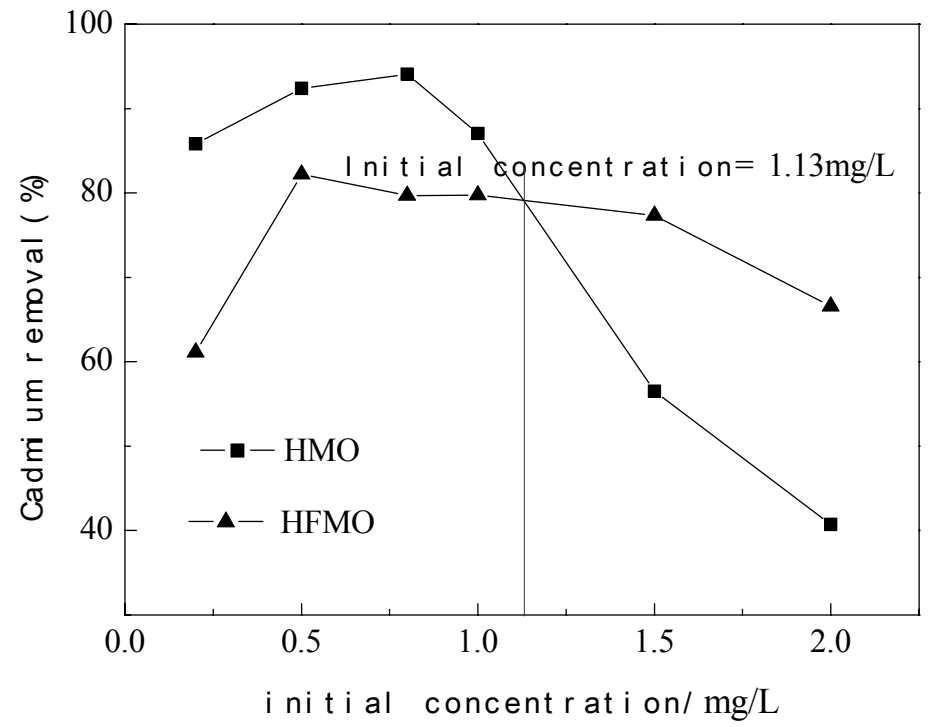

Figure 4. The effects of initial concentration of $\mathrm{Cd}^{2+}$ on the removal efficiency of $\mathrm{Cd}(\mathrm{II})$ in synthetic water by HMO and HFMO

(The dosage of HMO and HFMO is $20 \mathrm{mg} / \mathrm{L}, 28.14 \mathrm{mg} / \mathrm{L}$, separately)

\subsection{Effect of coagulation time}

In order to evaluate the effect of coagulation time on $\mathrm{Cd}(\mathrm{II})$ removal, coagulation experiments were conducted in the coagulation time from 2 min to 60min. As demonstrated in Figure 5, it is evident that Cd(II) can be removed very quickly at the rapid mixing stage. In the first $2 \mathrm{~min}$, the removal of Cd(II) achieves $96.29 \%$ and $83.23 \%$ respectively by HMO and HFMO. Afterwards, the removal efficiency fluctuated within a small range.

\subsection{Cadmium removal in the Canal Jingmi}

Figure 6 shows the effect of coagulants dosage on the removal of cadmium by two manganese coagulants in natural water. It is observed that the removal efficiency variety in natural water is similar to the way in the synthetic water for HMO. When the dosage of the $\mathrm{HMO}$ is less than $8 \mathrm{mg} / \mathrm{L}$, the cadmium removal in natural water is better than in synthetic one because the alkalinity environment and the suspended substance enhanced the removal of the cadmium. But the cadmium removal in the natural water did not show any advantage after the dosage bigger than $8 \mathrm{mg} / \mathrm{L}$. This is due to the competing cations existed in the natural water inhibited the adsorption of the cadmium.

As far as HFMO, the removal efficiency in natural water is much higher than in synthetic water. This is also attributed to the alkalinity environment and the adsorption of the cadmium by suspended substance. The inserted figure shows that the turbidity after precipitation of the natural water treated by HFMO is very high and cannot satisfy the standards for drinking water quality. This restrains the application of the HFMO in water industry. 


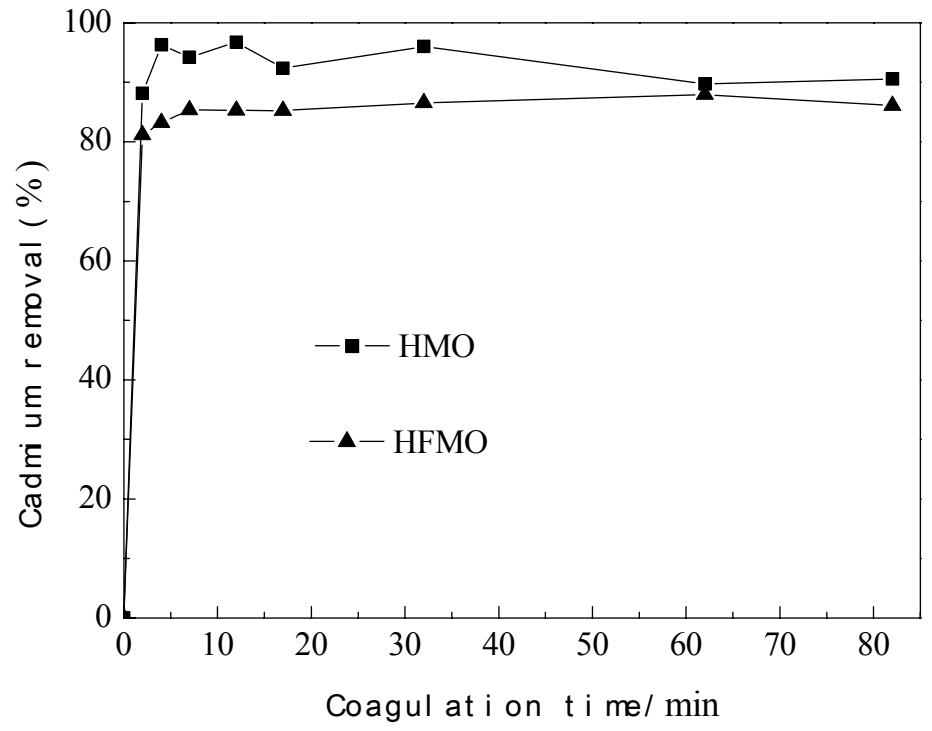

Figure 5. The effects of coagulation time on the removal efficiency of $\mathrm{Cd}(\quad)$ in synthetic water by HMO and HFMO (The dosage of HMO and HFMO is $20 \mathrm{mg} / \mathrm{L}, 28.14 \mathrm{mg} / \mathrm{L}$, separately)

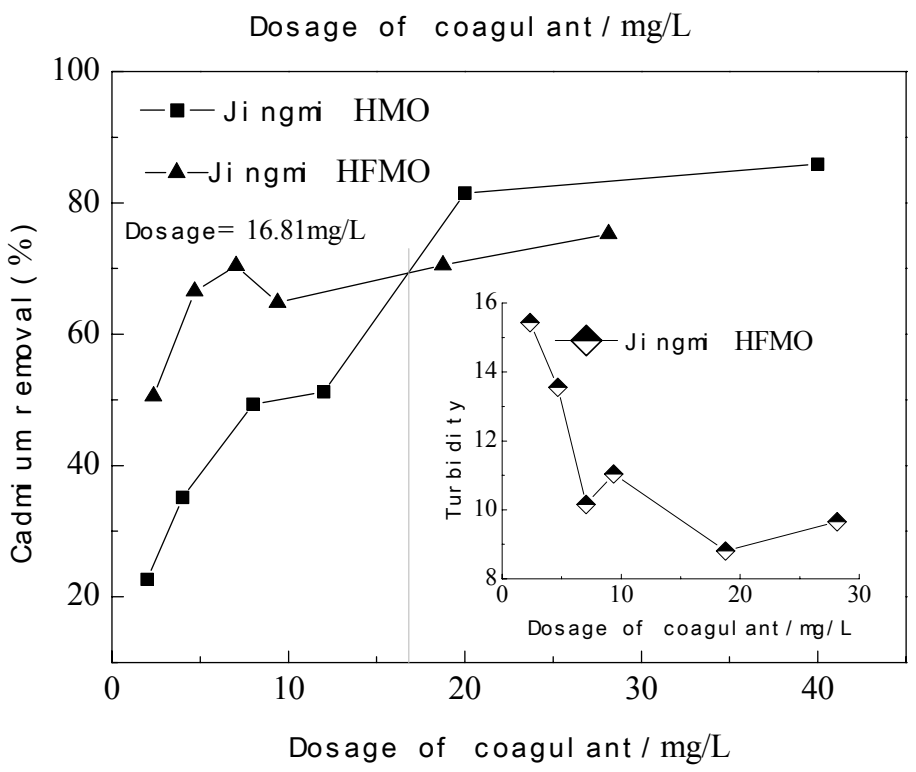

Figure 6. The removal efficiency of Cd(II) in raw water of Canal Jingmi of Beijing by HMO and HFMO(The inserted figure shows the turbidity after precipitation treated by HFMO)

\section{Conclusions}

This study examined $\mathrm{Cd}(\mathrm{II})$ removal by two different manganese coagulants. The obtained results can be summarized as follow:

(1) HMO has a better cadmium removal efficiency and optimum Cd(II) removal by HMO was achieved at a HMO dosage of $20 \mathrm{mg} / \mathrm{L}$. As for HFMO, the removal efficiency of cadmium decreased when the dosage is bigger than $28.14 \mathrm{mg} / \mathrm{L}$.

(2) Turbidity has little effect on the cadmium removal by HMO, but it significantly promotes the cadmium removal by HFMO. The change of the turbidity has slightly effect on the cadmium removal for both manganese salt coagulants.

(3) The cadmium removal is highly pH-dependent. The removal efficiency of the cadmium is bad under the acidic environment. However, the removal efficiency increases quickly with increasing of the $\mathrm{pH}$.

(4) The initial concentration of the cadmium significantly affects the cadmium removal by HMO and optimum cadmium (II) 
removal was achieved at a initial concentration of $1 \mathrm{mg} / \mathrm{L}$. However, the initial concentration has slightly effect on the cadmium removal by HFMO.

(5) Cadmium (II) can be removed very fast and most of it is removed at the rapid mixing stage. When the coagulation time is just 2 min, the percentage removal of Cd(II) by HMO and HFMO reached $96.29 \%$ and $83.23 \%$, respectively.

(6) The removal efficiency change in natural water is similar to the way in the synthetic water for HMO. As far as HFMO, the removal efficiency in natural water is much higher than in synthetic water. But the turbidity after precipitation of the natural water treated by HFMO is very high and cannot satisfy the standards for drinking water quality.

\section{References}

Ayoub G.M., Semerjian L., Acra A., EI- Fadel M. and Koopman B., 2001. Heavy metal removal by coagulation with seawater liquid bittern. Journal of Environment Engineering, Vol.127, No. 3, pp. 196-207.

Bhattacharya A.K. and Venkobacher C., 1984. Removal of cadmium(II) by low cost adsorbents. Environment. Engineering., Vol.110, No. 3, pp. 110-116.

Brantner K.A. and Cichon E.J.. Proc., 1984. $16^{\text {th }}$ Mid-Atlantic Industrial Waste Conference, pp. 43-56.

Casas I., Miralles N., Sastree A. and Aguilar M., 1986. Extraction of cadmium(II) by organophosphorous compound. Polyhedron, Vol.5, No.12, pp. 2039-2046.

Chen W.L., 2008. Removal of cadmium (II) from micro-polluted raw water by enhanced coagulation process. Water and Waste Water (in Chinese), Vol. 11, No. 34, pp. 129-133.

Christensen E.R. and Delwiche J.T., 1982. Removal of heavy metals from electroplating rinse water by precipitation, flocculation and ultrafiltration. Water Research, Vol. 16, No 5, pp. 729-737.

Das N. and Jana R.K., 2006. Adsorption of some bivalent heavy metal ions from aqueous solutions by manganese nodule leached residues. Journal of Colloid and Interface Science, Vol. 293, No.2, pp. 253-262.

Guan X., Chen G. and Shang C.., 2007. Adsorption behavior of condensed phosphate on aluminum hydroxide. Journal of Environmental Sciences, Vol. 19,No.3, pp. 312-318.

Gupta V.K. and Sharma S.., 2002. Removal of cadmium and zinc from aqueous solutions using red mud. Environmental Science and Technology, Vol.36, No.16, pp: 3612-3617.

Hrudey S.E., 1984. Special residue management for Alberta, R\&D Report, University of Alberta, 84/27,172.

Marder L., Guilherme O.S., Andrea M.B. and Z.F. Jane Z.F., 2003. Removal of cadmium and cyanide from aqueous solutions through electrodialysis. Journal of the Brazilian Chemical Society, Vol.14, No. 4, pp. 610-615.

Mazid M., 1984. Mechanisms of transport through reverse osmosis membrane. Separation Science and Technology, Vol.19, No.67, pp. 357-363.

Mohapatra M., Rout K., Mohapatra B.K. and Anand S., 2009. Sorption behavior of $\mathrm{Pb}$ (II) and $\mathrm{Cd}(\mathrm{II})$ on iron ore slime and characterization of metal ion loaded sorbent. Journal of Hazardous Materials, Vol.166, No.2-3, pp. 1506-1513.

Naiya T.K., Bhattacharya A.K. and S. K. Das S.K. 2009. Adsorption of $\mathrm{Cd}(\mathrm{II})$ and $\mathrm{Pb}(\mathrm{II})$ from aqueous solutions on activated alumina. Journal of Colloid and Interface Science, Vol. 333, No.1, pp. 14-26.

Ozturk S., Aslim B., and Turker A.R. 2009. Removal of cadmium ions from aqueous samples by synechocystis sp. Separation Science and Technology, Vol. 44, No.6, pp. 1467-1483.

Tripathy S.S., Bersillon J.-L. and Gopal K., 2006. Adsorption of $\mathrm{Cd}^{2+}$ on hydrous manganese dioxide from aqueous solutions. Desalination, Vol.194, No.1-3, pp. 11-21.

Tripathy S.S., Sarangi K. and Das R.P., 2002. Extraction of cadmium (II) by supported liquid membrane using TOPS-99 as mobile carrier. Separation Science and Technology, Vol.37, No.12, pp. 2897-2904.

Stenstrom S., 1987. Extraction of cadmium from phosphoric acid solutions with amines. Part III. A thermodynamic extraction model. Hydrometallurgy, Vol.18, No.1, pp. 1-4.

Sharma Y.C., 1995. Economic treatment of cadmium (II) rich hazardous waste by indigenous material. Journal of Colloid and Interface Science, Vol.173, No.1, pp. 66-69.

Singh D.B., Rupainwar D.C., Prasad G. and Jayaprakas K.C., 1998. Studies on the Cd(II) removal from water by adsorption. Journal of Hazardous Materials, Vol. 60, No. 1, pp. 29-40.

Tonkin J.W., Balistrieri L.S. and Murray J.W., 2004. Modeling sorption of divalent metal cations on hydrous manganese oxide using the diffuse double layer model. Applied Geochemistry, Vol.19,No 1, pp. 29-53.

Wu J., Lu J., Chen T., He Z., Su Y., Jin X. and Yao X., 2010. In situ biotreatment of acidic mine drainage using straw as sole substrate. Environmental Earth Sciences, Vol. 60, No.2, pp. 421-429.

Yang W., 2008. The mechanism and application of hydrous manganese dioxide in water treatment (in Chinese). Beijing: Chemistry Industrial Press.

\section{Biographical notes}

Yongpeng Xu received Ph.D. from Harbin Institute of Technology, China in 2004. She is an Associate Professor in the Department of Municipal Engineering, Harbin Institute of Technology, China. She has more than 10 years of experience in teaching and research. Her current area of research includes the fate of 
emerging compounds in water environment, the optimization of drinking water treatment, the application of ultra-membrane in water treatment. She is currently dealing with a few projects sponsored by government of China.

Leisan Yang received M.S form Harbin Institute of Technology, China in 2010. He is an Engineer in the Architectural Design and Research Institute of Guangdong Province, China.

Jinkun Yang is a graduate student in Harbin Institute of Technology.

Received April 2010

Accepted September 2010

Final acceptance in revised form September 2010 